\title{
Business Retention and Expansion (BRE) Programs: Why Existing Businesses Are Important ${ }^{1}$
}

Henry M. Cothran²

\section{Introduction}

Recruitment as an economic development activity has its limitations. Many times, community leaders and the media are caught up in the excitement of luring new companies to their area, only to realize that they are replacing companies who have been 'lured' someplace else (Maples, 1996).

Few people would argue with the assertion that existing businesses are important to the local economy. Over the last two decades studies have documented the impact of existing businesses on job growth. Other studies have examined the impact of businesses on maintaining strong local economies through investments in the social fabric of the community. Finally, existing businesses are always a primary source of information about the community for companies looking to relocate.

This publication is first in a series on establishing Business Retention and Expansion programs. The publications in this series can be found online at the EDIS website at http://edis.ifas.ufl.edu/TOPIC_SERIES_BRE.

\section{Why Existing Businesses Are Important}

\section{Existing Businesses Create More New Jobs}

A number of studies have documented the net new job growth attributable to existing businesses. Whether these studies looked at state or national data, all concluded that job growth from existing businesses far exceeds job growth that was the result of industry attraction.

- In Job Creation in America (Birch, 1987), the author reported that up to 80 percent of net new job growth comes from existing businesses. Today, virtually every economic development organization uses that percentage when asked about the importance of existing businesses to his/her community.

\section{- In Retention First, Ohio's Challenge}

(Kraybill,1995), the author reported average Ohio job growth of 70 percent from existing businesses, with rural areas experiencing as much as 86 percent of net job growth from existing businesses.

1. This is EDIS document FE651, a publication of the Food and Resource Economics Department, Florida Cooperative Extension Service, Institute of Food and Agricultural Sciences, University of Florida, Gainesville, FL. Published September 2006. Please visit the EDIS website at http://edis.ifas.ufl.edu.

2. Henry M. Cothran, Associate In, Food and Resource Economics Department, Florida Cooperative Extension Service, Institute of Food and Agricultural Sciences, University of Florida, Gainesville, FL.

The Institute of Food and Agricultural Sciences (IFAS) is an Equal Opportunity Institution authorized to provide research, educational information and other services only to individuals and institutions that function with non-discrimination with respect to race, creed, color, religion, age, disability, sex, sexual orientation, marital status, national origin, political opinions or affiliations. U.S. Department of Agriculture, Cooperative Extension Service, University of Florida, IFAS, Florida A. \& M. University Cooperative Extension Program, and Boards of County Commissioners Cooperating. Larry Arrington, Dean 
- A 1990 survey by Arthur D. Little and the American Economic Development Council document job growth from existing businesses in four states (Phillips, 1996).

1. Illinois - from 31 to 58 percent.

2. Nebraska - from $38-59$ percent.

3. Tennessee - from 47 to 72 percent.

4. Wisconsin - from 41 to 61 percent.

- In terms of job creation and tax contributions, the expansion of businesses and operations, not new operations, has the greater impact in most communities over time (Gordon, 2001).

- There are literally thousands of communities involved in industry attraction, yet fewer than 200 major plant relocations occur annually (Kotval, et al., 1996). Thus basing an economic development strategy solely on landing a "big fish" has only a small chance of success.

\section{Existing Businesses Invest in the Community}

Aside from the fact that existing businesses create new jobs, there are a number of other reasons that are often cited to document the value of existing businesses.

- Existing businesses that make investments in facilities, create jobs, and pay taxes are at the heart of strong local economies (Maples, 1996).

- Existing businesses already have a stake in the community and are demonstrably contributing to the economic vitality and social fabric of the community (Morse, 2004).

- Business owners know that it is easier and less expensive to retain existing customers. The same thing is true for communities that focus on retaining existing businesses (Maples, 1996).

- Keeping a business in your community is less costly than attracting new industry. Industry attraction efforts often include significant tax incentives and substantial infrastructure development costs. Existing businesses may seek some of these incentives, but more often than not, the fiscal cost per job created is less for an existing business than for a new business (Morse, 2004).

- Keeping what you have is good for the development and growth of smaller firms. Businesses that export goods and services generate the revenue that funds smaller, local, service businesses. Both types of firms are necessary and the service firms may not survive if the exporting firms close or move away (Kotval, et al., 1996).

- Every economy loses about 10 percent of its jobs annually due to retirements, business closings, product life cycles, etc. Existing businesses are best positioned locally to replace those jobs (Kotval, et al., 1996).

\section{Existing Businesses Are Ambassadors for Industry Recruitment}

Building on existing community business strengths has proven to be a successful industry recruitment strategy.

- Finding and fixing problems for existing businesses may identify businesses for targeted recruitment efforts (Gordon, 2001).

- Satisfied existing businesses can be a community's best ambassadors when recruiting new firms to the area as well as serving as a source of leads when seeking new firms to recruit (Morse, 2004).

- If an existing business is a thriving and growing concern, or is viewed as having growth potential, it may be the target of recruitment activities by another community. Thus it is in the best interests of local communities to make every effort to retain them.

\section{Conclusion}

There can be little doubt that existing businesses are important to the local community and its economy. This publication has identified some of the more commonly cited reasons used by economic professionals when planning and implementing an existing business program. The challenge for the 
economic development professional is to effectively communicate to the local community the value of these businesses to the community and its economy.

\section{References}

Birch, D. 1987. Job Creation in America. New York, NY: Free Press/MacMillan Publishing Company.

Birch, D., J. Gunderson, A. Haggerty, and W. Parsons. 1993. Who's Creating Jobs? Mimeo, Cognetics, Inc., Cambridge, MA.

Gordon, G. 2001. Retention and Expansion of Existing Businesses. West Virginia University Extension Service, Morgantown, WV.

Kraybill, D. 1995. Retention and Expansion First. Ohio's Challenge 8(2):4-7 [Department of Agricultural, Environmental, and Development Economics, Ohio State University, Columbus, $\mathrm{OH}]$.

Kotval, Z., J. Mullin, and K. Payne. 1996. Business Attraction and Retention: Local Economic Development Efforts. International City/County Management Association, Washington, D.C.

Maples, M. 1996. Business Retention: The Basics and Beyond. Economic Development Review 14(3): 4 -7

Morse, G. 2004. The Retention and Expansion of Existing Businesses. CARDI-Cornell, Ithaca, NY. http://www.cdtoolbox.net/economic_development/ 000195.html.

Phillips, Phillip D. 1996. Business Retention and Expansion: Theory and an Example in Practice. Economic Development Review 14(3): 8-13. 